Communication

\title{
Synergy of Thermochemical Treatment of Dried Distillers Grains with Solubles with Bioethanol Production for Increased Sustainability and Profitability
}

\author{
Samuel O’Brien ${ }^{1}$, Jacek A. Koziel ${ }^{1, *}\left(\mathbb{D}\right.$, Chumki Banik ${ }^{1}\left(\mathbb{1}\right.$ and Andrzej Białowiec ${ }^{1,2}{ }^{(1)}$ \\ 1 Department of Agricultural and Biosystems Engineering, Iowa State University, Ames, IA 50011, USA; \\ scobrien@iastate.edu (S.O.); cbanik@iastate.edu (C.B.); andrzej.bialowiec@upwr.edu.pl (A.B.) \\ 2 Institute of Agricultural Engineering, The Faculty of Life Sciences and Technology, Wrocław University of \\ Environmental and Life Sciences, 37a Chełmońskiego Str., 51-630 Wrocław, Poland \\ * Correspondence: koziel@iastate.edu; Tel.: +1-515-294-4206
}

Received: 7 July 2020; Accepted: 30 August 2020; Published: 1 September 2020

\begin{abstract}
The bioethanol industry continues improving sustainability, specifically focused on plant energy and GHG emission management. Dried distiller grains with solubles (DDGS) is a byproduct of ethanol fermentation and is used for animal feed. DDGS is a relatively low-value bulk product that decays, causes odor, and is challenging to manage. The aim of this research was to find an alternative, value-added-type concept for DDGS utilization. Specifically, we aimed to explore the techno-economic feasibility of torrefaction, i.e., a thermochemical treatment of DDGS requiring low energy input, less sophisticated equipment, and resulting in fuel-quality biochar. Therefore, we developed a research model that addresses both bioethanol production sustainability and profitability due to synergy with the torrefaction of DDGS and using produced biochar as marketable fuel for the plant. Our experiments showed that DDGS-based biochar (CSF-carbonized solid fuel) lower calorific value may reach up to $27 \mathrm{MJ} \cdot \mathrm{kg}^{-1} \mathrm{~d}$.m. (dry matter) Specific research questions addressed were: What monetary profits and operational cost reductions could be expected from valorizing DDGS as a source of marketable biorenewable energy, which may be used for bioethanol production plant's demand? What environmental and financial benefits could be expected from valorizing DDGS to biochar and its reuse for natural gas substitution? Modeling indicated that the valorized CSF could be produced and used as a source of energy for the bioethanol production plant. The use of heat generated from CSF incineration supplies the entire heat demand of the torrefaction unit and the heat demand of bioethanol production (15-30\% of the mass of CSF and depending on the lower heating value (LHV) of the CSF produced). The excess of 70-85\% of the CSF produced has the potential to be marketed for energetic, agricultural, and other applications. Preliminary results show the relationship between the reduction of the environmental footprint ( $\sim 24 \%$ reduction in $\mathrm{CO}_{2}$ emissions) with the introduction of comprehensive on-site valorization of DDGS. The application of DDGS torrefaction and CSF recycling may be a source of the new, more valuable revenues and bring new perspectives to the bioethanol industry to be more sustainable and profitable, including during the COVID-19 pandemic and other shocks to market conditions.
\end{abstract}

Keywords: biofuel; biorenewables; corn; DDGS; ethanol; sustainability; torrefaction; waste-to-energy; waste-to-carbon; CSF 


\section{Introduction}

The production of bioethanol is a heat-consuming process. The heat demand for processing of corn is $\sim 1100 \mathrm{MJ} \cdot \mathrm{Mg}^{-1}$ (corn), while the production of bioethanol requires $38,600 \mathrm{MJ} \cdot \mathrm{Mg}^{-1}$ (bioethanol). Typically, this heat demand is supplied by the incineration of natural gas, a fossil fuel [1]. Therefore, the production of bioethanol is not considered sustainable (e.g., due to net GHG production, [2]), which is dependent on fluctuating prices of natural gas and subsidies. The bioethanol production industry needs continued efforts to be profitable, sustainable, self-sufficient, and independent from the volatile fuels market and resilient to changing policies.

We propose, for the first time, implementation of the new solution based on valorization and waste recycling according to 'waste to carbon' and 'waste to energy' approaches. One of the bioethanol industry waste is dried distiller grains with solubles (DDGS) accounting for $\sim 30 \%$ [1] of the initial mass of corn. Wet DDGS is usually used for animal feeding with relatively low revenues for the ethanol plant. The wet (unprocessed) DDGS are prone to decay and are difficult to store without drying (and additional energy input for drying is required) [3].

We propose the use of torrefaction (roasting at 200 to $600{ }^{\circ} \mathrm{C}$ in the absence of oxygen) of DDGS to produce biochar. The biochar (i.e., carbonized DDGS, also known as carbonized solid fuel, CSF [4]) is then used as a fuel to that covers the entire heat needs for a bioethanol plant. The biochar produced from DDGS may reach the calorific value up to $\sim 27 \mathrm{MJ} \cdot \mathrm{kg}^{-1} \mathrm{~d} . \mathrm{m}$. (equivalent of high-quality coal, anthracite) while the mass yield of the biochar is $60-90 \%$.

The proposed solution is an innovative change in the bioethanol production scheme due to: (i) addition of a torrefaction unit for thermochemical treatment of DDGS and production of biochar (CSF) characterized by improved fuel properties; (ii) substitution of CSF for natural gas (currently used as the heat source in a gas boiler) and incineration in a solid fuel boiler; (iii) use of heat generated from CSF incineration in solid fuel boiler for covering entire heat demands of torrefaction unit and the heat demand of bioethanol production process. The residual mass of CSF produced has the potential to be marketed for energetic, agricultural, and other applications.

In this paper, we present a techno-economic analysis showing that the proposed valorization of DDGS is profitable, i.e., it makes the bioethanol plant energy-neutral (for heat) while creating additional revenue streams from CSF sold outside. A few techno-economic models for bioethanol plants were developed. Kwiatkowski et al. created a model of the ethanol production system through the dry-grind process [1]. The model was created with the goal of being applied to the evaluation of current and new grain conversion technologies, to assist in the determination of how impactful alternative feedstocks can be, and for sensitivity analysis of high impact economic factors. As such, the model was not based on generic plant design. The model uses data from ethanol producers, manufacturers of the equipment, suppliers, and engineers in this field. The Kwiatkowski et al. [1] model was created to simply be a baseline for a standard ethanol production system.

Kalyian et al. [2] developed a model of a process that integrated torrefied corn stover into the ethanol production system. The goal of this model was to assess whether there was the potential to reduce greenhouse gas emissions through the integration of biomass torrefaction into industrial-scale businesses. Our model has a different scope in comparison to Kalyian et al. [2] because the biomass we propose as a feedstock for torrefaction is a direct byproduct of ethanol production. We are using DDGS for biochar production, which, in turn, could potentially earn positive carbon abatement effects.

We aimed to explore the techno-economic feasibility of torrefaction, i.e., a thermochemical treatment of DDGS requiring low energy input, less sophisticated equipment, and resulting in fuel-quality biochar. Therefore, we developed a research model that addresses both bioethanol production sustainability and profitability due to synergy with the torrefaction of DDGS and using produced biochar as marketable fuel for the plant. Specific research questions addressed were:

1. What monetary profits and operational cost reductions could be expected from valorizing DDGS as a source of marketable biorenewable energy? 
2. What fraction of energy demand for bioethanol production could be supplied by CSF from DDGS?

3. What environmental and financial benefits could be expected from valorizing DDGS to CSF and its reuse for natural gas substitution?

\section{Materials and Methods}

\subsection{Techno-Economic Model}

A techno-economic model was created to provide an initial evaluation of the proposed concept. The model was based on data collected regarding ethanol production requirements and products [1]. Using these data, we were able to create a working model for a standard ethanol production system that can work with some key inputs such as the mass of corn being used, or the capacity of the plant, to generate information on the products and byproducts that would be produced as a result. What we used this information for was to create a hands-on model of our own so that we could compare a generic ethanol production system with our own proposed ethanol production system. The data in this paper was critical in the creation of our mass and energy balances, which were used to determine the viability of our proposed method. This whole model was created in Microsoft Excel (Supplementary Materials, Technoeconomic Model.xlsx).

The document itself contains several tabs providing information on the system and what is occurring in each step of the process. Among these tabs is a flowchart that provides not only a visual representation of the ethanol production system but also a detailed look at the mass breakdown at every step. A more detailed overview of what each tab contains can be seen in Table 1.

To make the model more user-friendly and organized, we used different colors to symbolize different processes in the flowchart. For example, the corn cleaning process is highlighted in Figure 1. The 'Total Corn' block is colored green as it is an input into the system, the 'Cleaning' block is colored blue to signify that it is a process in the system, and the 'Trash' block is red to signify a byproduct of the system that is not profitable. The only block not pictured is that of a profitable byproduct, which is colored in orange. On top of the color-coded blocks, several cells are colored yellow or orange, which yellow indicating values that are inputted and orange, indicating values that change as a result of the values in yellow.
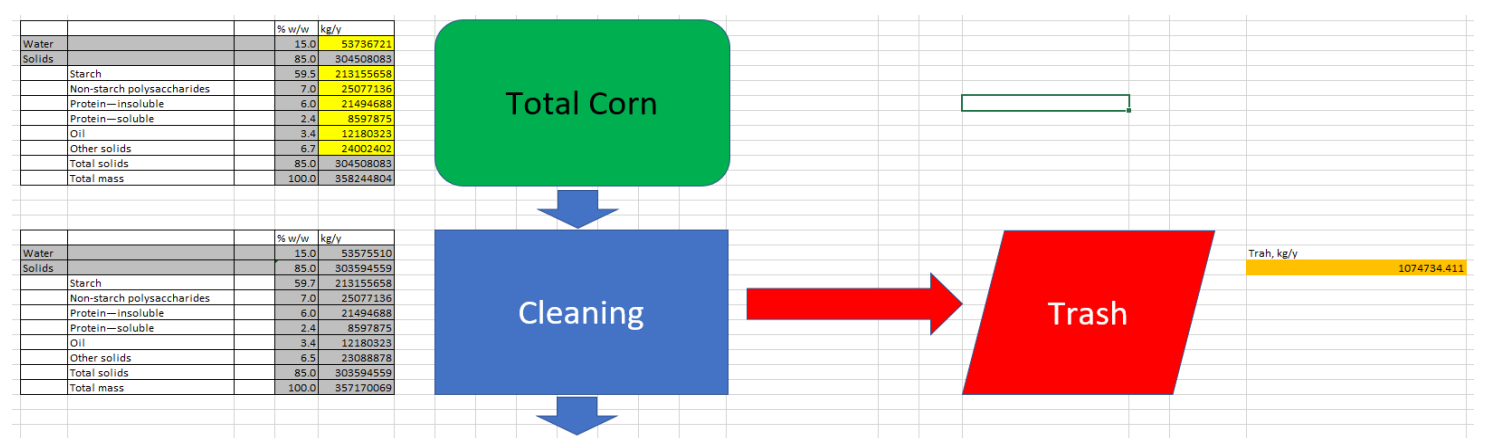

Figure 1. The cleaning process from the 'Flowchart' page in the Supplementary Materials (Excel spreadsheet, Technoeconomic Model).

An example of the techno-economic model is given in Figure 2, presenting the part of the mass balance of the bioethanol plant.

The developed techno-economic model was a source of the mass balance data for the simplified economic analysis of bioethanol plants. For calculations, we used four main components of the bioethanol plant:

- Corn prices as a cost.

- Natural gas prices as a cost. 
- Ethanol prices as a revenue.

- DDGS prices as a revenue.

Additionally, in the scenario with the application of the torrefaction, we included the option of selling the CSF on the market. We assumed that the price of revenue would be similar to the price of biochar available as a soil amendment. We determined the CSF threshold price above which the bioethanol plant with implemented DDGS torrefaction starts to have higher profits than the conventional one.

Table 1. Legend to the Technoeconomic Model (Excel spreadsheet in Supplementary Materials): Bioethanol Plant Production Model.

\begin{tabular}{|c|c|c|c|}
\hline Excel Tab (Name) & Function & Inputs & Outputs \\
\hline Introduction & Brief explanation of what the file contains & NA & NA \\
\hline Flowchart & $\begin{array}{l}\text { Visual representation of ethanol production } \\
\text { with the breakdown of the mass. }\end{array}$ & NA & $\begin{array}{ll}- & \text { Mass of trash } \\
- & \text { Mass of ethanol } \\
- & \text { Mass of DDGS } \\
\text { - } & \text { Mass of } \mathrm{CO}_{2} \\
\end{array}$ \\
\hline Substrate-corn & $\begin{array}{l}\text { Provides information regarding the mass } \\
\text { composition of corn. }\end{array}$ & $\begin{array}{l}\text { - } \quad \text { Yearly plant working hours } \\
\text { - } \quad \text { Annual cost of corn } \\
\text { - } \quad \text { Current corn price } \\
\text { - }\end{array}$ & NA \\
\hline Additives & $\begin{array}{l}\text { Summary of the mass of all additives during } \\
\text { the process. }\end{array}$ & - Water use & NA \\
\hline Cleaning & Detailed description of the cleaning stage. & NA & NA \\
\hline Grinding & $\begin{array}{l}\text { Brief description of grinding and its relation to } \\
\text { the mass balance. }\end{array}$ & NA & NA \\
\hline Weigh Tank & $\begin{array}{l}\text { Brief description of the weigh tank phase and } \\
\text { its relation to the mass balance. }\end{array}$ & NA & NA \\
\hline Slurry Tank & $\begin{array}{l}\text { Breakdown of how the mass changes into a } \\
\text { slurry and its resultant composition. }\end{array}$ & $\begin{array}{ll}\text { - } & \text { Mass of } \alpha \text {-amylase } \\
\text { - } & \text { Ammonia } \\
\text { - } & \text { Lime } \\
\text { - } & \text { Water }\end{array}$ & NA \\
\hline Liquefaction & $\begin{array}{l}\text { Brief overview of the liquefaction step and the } \\
\text { conversation of the starch to oligosaccharides. }\end{array}$ & NA & NA \\
\hline Saccharification & $\begin{array}{l}\text { Brief overview of the saccharification step and } \\
\text { the conversation of oligosaccharides to glucose. }\end{array}$ & NA & NA \\
\hline Fermentation & $\begin{array}{l}\text { Detailed look at the fermentation step and } \\
\text { conversion rates to ethanol and biomass. }\end{array}$ & NA & NA \\
\hline Beer Column & $\begin{array}{l}\text { Brief overview of the routes the mass takes } \\
\text { from the beer column. }\end{array}$ & NA & NA \\
\hline Centrifugation & $\begin{array}{l}\text { Description of centrifugation and assumptions } \\
\text { for centrifuge capacity. }\end{array}$ & NA & NA \\
\hline Ethanol Purification & $\begin{array}{l}\text { Overview of the ethanol purification process as } \\
\text { well as steam use. }\end{array}$ & NA & - $\quad$ Ethanol produced \\
\hline Evaporation & Mass of water evaporated during purification. & NA & NA \\
\hline
\end{tabular}

NA—not applicable.

In our model, we used the most recent prices and costs given by the Hofstrand [5], which were converted to the relative price to a ton of corn. In our economic model, we included following components: Materials (Corn, Denaturant, Enzymes, Yeast, Chemicals, Other); Utilities (Electricity, Water, Natural Gas); Fixed costs (Labor and Management, Repairs and Maintenance, Property Taxes, Depreciation, Transportation, Interest); and Ethanol, DDGS, CSF.

All pricing data are given in Tables 2 and 3. The current price of biochar has been used to characterize the economic value of the CSF [6]. On the base of price data and mass and energy balances, we created the simplified economic model of these scenarios, which is available in the Supplementary Materials as an Economic analysis.xlsx file. 


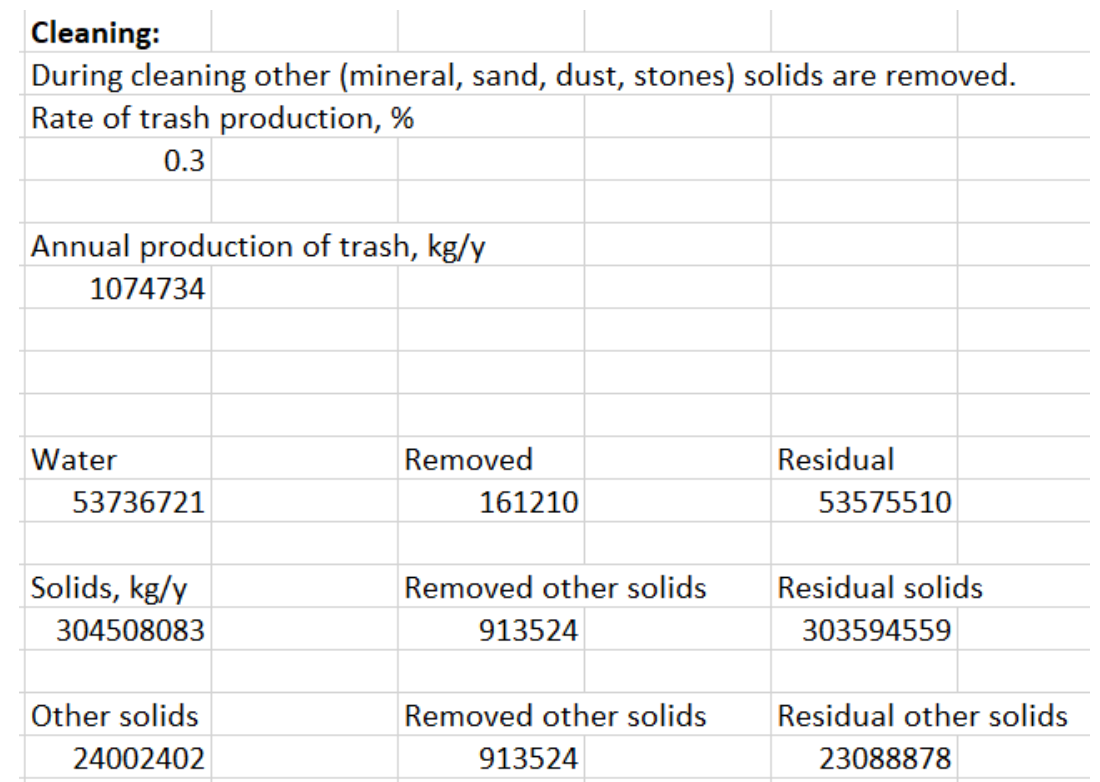

Figure 2. Information provided in the 'Cleaning' page from the Supplementary Material (Excel spreadsheet, Technoeconomic Model).

Table 2. The economic analysis of the conventional bioethanol plant on the basis of the mass balance of the main components and prices.

\begin{tabular}{|c|c|c|c|c|c|c|}
\hline $\begin{array}{l}\text { Bioethanol } \\
\text { Plant Model } \\
\text { Component }\end{array}$ & Reference & $\begin{array}{l}\text { The Price Per Mass } \\
\text { Equivalent of } \\
\text { Model Component, } \\
\text { \$.ton }{ }^{-1}\end{array}$ & $\begin{array}{c}\text { The Price Per Mass } \\
\text { Equivalent of Corn of } \\
\text { the Model Component, } \\
\$ \cdot \text { ton }^{-1} \text { Corn }\end{array}$ & $\begin{array}{l}\text { Mass of Model } \\
\text { Component, } \\
\mathbf{t} \cdot \mathbf{y}^{-1}\end{array}$ & Costs, $\$ \cdot y^{-1}$ & $\begin{array}{c}\text { Revenues, } \\
\$ \cdot y^{-1}\end{array}$ \\
\hline Corn & {$[1,5]$} & 122 & - & 358,250 & $43,705,866$ & - \\
\hline Denaturant & [5] & - & 5.14 & - & $1,840,306$ & - \\
\hline Yeast & [5] & - & 0.37 & - & 134,271 & - \\
\hline Chemicals & [5] & - & 3.57 & - & $1,279,526$ & - \\
\hline Other & [5] & - & 2.20 & - & 789,831 & - \\
\hline \multicolumn{7}{|c|}{ Utilities } \\
\hline \multicolumn{7}{|c|}{ Fixed costs } \\
\hline $\begin{array}{c}\text { Labor and } \\
\text { Management }\end{array}$ & [5] & - & 4.19 & - & $1,502,115$ & - \\
\hline $\begin{array}{l}\text { Repairs and } \\
\text { Maintenance }\end{array}$ & [5] & - & 2.76 & - & 987,289 & - \\
\hline Property Taxes & [5] & - & 0.25 & - & 89,754 & - \\
\hline Depreciation & [5] & - & 4.67 & - & $1,674,442$ & - \\
\hline Transportation & [5] & - & 0.83 & - & $2,96,187$ & - \\
\hline Interest & [5] & - & 6.99 & - & $2,502,742$ & - \\
\hline
\end{tabular}




\section{Calculation of Energy Demand for Torrefaction of DDGS}

The results from the DSC analyses were used to calculate the actual energy demand in processing dry DDGS (to heat DDGS from $20^{\circ} \mathrm{C}$ to $260^{\circ} \mathrm{C}$ ) according to the procedure described by Świechowski et al. [7]. It has been assumed that DDGS is dried, and energy is not spent on water evaporation. The energy demand for DDGS drying is included in the natural gas demand of bioethanol plant. The energy needed to DDGS torrefaction was calculated by Equation (1):

$$
Q=m \cdot \Delta T \cdot c p
$$

where:

$Q$ —the total amount of heat needed to heat DDGS, GJ. $\mathrm{y}^{-1}$,

$m$-the mass of the DDGS, $\mathrm{t} \cdot \mathrm{y}^{-1}$,

$\Delta T$ - the temperature difference between ambient temperature $\left(20^{\circ} \mathrm{C}\right)$ and torrefaction point $\left(260^{\circ} \mathrm{C}\right)$, under normal pressure conditions, ${ }^{\circ} \mathrm{C}$,

$c p$-specific heat of DDGS, $1.6 \mathrm{~kJ} \cdot\left(\mathrm{kg} \cdot{ }^{\circ} \mathrm{C}\right)^{-1}$.

\subsection{Production of CSF}

Corn DDGS originated from commercial provider [8] "Goświnowice" Ethanol Plant Głębinów, Poland. DDGS torrefaction was done according to Syguła et al. [9] in a muffle furnace (SNOL 8.1/1100, Utena, Lithuania). $\mathrm{CO}_{2}$, with a flow rate of $10 \mathrm{dm}^{3} \cdot \mathrm{h}^{-1}$, was supplied to create oxygen-free conditions. The process was carried out under temperature $260^{\circ} \mathrm{C}$ during $60 \mathrm{~min}$ retention time. The samples were heated with a heating rate of $50{ }^{\circ} \mathrm{C} \cdot \mathrm{min}^{-1}$ from $20^{\circ} \mathrm{C}$ to the torrefaction setpoint temperature. Ten grams $( \pm 0.5 \mathrm{~g})$ of the dry mass of the sample was placed in the steel crucible. The CSF was removed from the muffle furnace when the interior temperature was lower than $200{ }^{\circ} \mathrm{C}$ (temperature was monitored by an internal thermocouple and visualized on the screen of the furnace). The approximate times of cooling from $260{ }^{\circ} \mathrm{C}$ to $200{ }^{\circ} \mathrm{C}$ was $29 \mathrm{~min}$, respectively.

Table 3. The economic analysis of the bioethanol plant with implemented torrefaction of DDGS on the base of the mass balance of the main components and prices of the main component of the techno-economic model of bioethanol plant.

\begin{tabular}{|c|c|c|c|c|c|c|}
\hline $\begin{array}{l}\text { Bioethanol } \\
\text { Plant Model } \\
\text { Component }\end{array}$ & Reference & $\begin{array}{l}\text { The Price Per Mass } \\
\text { Equivalent of } \\
\text { Model Component, } \\
\text { \$.ton }{ }^{-1}\end{array}$ & $\begin{array}{c}\text { The Price Per Mass } \\
\text { Equivalent of Corn of } \\
\text { the Model Component, } \\
\$ \cdot \operatorname{ton}^{-1} \text { Corn }\end{array}$ & $\begin{array}{c}\text { Mass of Model } \\
\text { Component, } \\
\mathbf{t} \cdot \mathbf{y}^{-1}\end{array}$ & Costs, $\$ \cdot y^{-1}$ & $\begin{array}{c}\text { Revenues, } \\
\$ \$ y^{-1}\end{array}$ \\
\hline Corn & {$[1,5]$} & 122 & - & 358,250 & $43,705,866$ & - \\
\hline Denaturant & [5] & - & 5.14 & - & $1,840,306$ & - \\
\hline Yeast & [5] & - & 0.37 & - & 134,271 & - \\
\hline Chemicals & [5] & - & 3.57 & - & $1,279,526$ & - \\
\hline Other & [5] & - & 2.20 & - & 789,831 & - \\
\hline \multicolumn{7}{|c|}{ Utilities } \\
\hline \multicolumn{7}{|c|}{ Fixed costs } \\
\hline $\begin{array}{c}\text { Labor and } \\
\text { Management }\end{array}$ & [5] & - & 4.19 & - & $1,502,115$ & - \\
\hline $\begin{array}{l}\text { Repairs and } \\
\text { Maintenance }\end{array}$ & {$[5]$} & - & 2.76 & - & 987,289 & - \\
\hline Property Taxes & [5] & - & 0.25 & - & 89,754 & - \\
\hline Depreciation & [5] & - & 4.67 & - & $1,674,442$ & - \\
\hline
\end{tabular}


Table 3. Cont.

\begin{tabular}{|c|c|c|c|c|c|c|}
\hline $\begin{array}{l}\text { Bioethanol } \\
\text { Plant Model } \\
\text { Component }\end{array}$ & Reference & $\begin{array}{l}\text { The Price Per Mass } \\
\text { Equivalent of } \\
\text { Model Component, } \\
\$ \cdot \text { ton }^{-1}\end{array}$ & $\begin{array}{l}\text { The Price Per Mass } \\
\text { Equivalent of Corn of } \\
\text { the Model Component, } \\
\$ \cdot \operatorname{ton}^{-1} \text { Corn }\end{array}$ & $\begin{array}{c}\text { Mass of Model } \\
\text { Component, } \\
t \cdot y^{-1}\end{array}$ & Costs, $\$ \cdot \mathbf{y}^{-1}$ & $\begin{array}{c}\text { Revenues, } \\
\$ \cdot y^{-1}\end{array}$ \\
\hline Transportation & [5] & - & 0.83 & - & $2,96,187$ & - \\
\hline Interest & [5] & - & 6.99 & - & $2,502,742$ & - \\
\hline Subtotal & - & - & - & - & $58,634,563$ & - \\
\hline \multicolumn{7}{|c|}{ Income } \\
\hline Ethanol & {$[1,5]$} & 398 & - & 124,000 & - & $49,344,040$ \\
\hline CSF & [10] & 2614 & - & 74,462 & - & $194,643,668$ \\
\hline Profit & & & $185,825,905$ & & & \\
\hline
\end{tabular}

\subsection{DDGS and CSF Analyses}

The DDGS and CSF samples were tested in three replicates of high heating value (HHV) and lower heating value (LHV), determined in accordance with [10], by means of the IKA C2000 calorimeter. The dried samples of raw DDGS were tested by differential scanning calorimetry (DSC) analyses, according to procedure and equipment described by Świechowski et al. [4] and the DDGS heat capacity $\left(c \mathrm{p}, \mathrm{kJ} \cdot\left(\mathrm{kg} \cdot{ }^{\circ} \mathrm{C}\right)^{-1}\right)$ was determined. The mass yield, energy densification ratio, and energy yield of CSF were determined based on Equations (2)-(4) [11], respectively:

$$
M Y=m_{b} / m_{a} \cdot 100
$$

where $M Y$ is the mass yield (\%), $m_{a}$ is the mass of raw material before torrefaction $(\mathrm{kg})$, and $m_{b}$ is the mass of CSF after torrefaction $(\mathrm{kg})$.

$$
E D r=H H V_{\mathrm{b}} / H H V_{\mathrm{a}}
$$

where $E D r$ is the energy densification ratio, $H H V b$ is the high heating value of $C S F\left(M J \cdot \mathrm{kg}^{-1}\right)$, and $H H V_{\mathrm{a}}$ is the high heating value of raw DDGS $\left(\mathrm{MJ} \cdot \mathrm{kg}^{-1}\right)$.

$$
E Y=M Y \cdot E D r
$$

where $E Y$ is the energy yield (\%), $M Y$ is the mass yield (\%), and $E D r$ is the energy densification ratio.

\section{Results}

\subsection{CSF Properties}

The DDGS torrefaction process carried under $260{ }^{\circ} \mathrm{C}$ and for $60 \mathrm{~min}$ was characterized by high biomass conversion efficiency. The mean HHV and LHV of DDGS were $20.76 \pm 0.45$ and $19.53 \pm 0.38 \mathrm{MJ} \cdot \mathrm{kg}^{-1}$ d.m., respectively, while CSF was characterized by HHV and LHV at $27.03 \pm 0.31$ and $26.12 \pm 0.27 \mathrm{MJ} \mathrm{J} \cdot \mathrm{kg}^{-1} \mathrm{~d}$.m., respectively. The energy densification ratio was 1.3 . The mass yield was $77.3 \pm 0.7 \%$. In total, the energy yield reached $100.6 \%$.

\subsection{Conventional Bioethanol Plant Techno-Economic Model}

The schematic below shows the simplified technological process of bioethanol production from corn. It requires natural gas (for heat) and generates waste (a highly unstable, difficult to manage and store byproduct, DDGS) (Figure 3).

Based on the model, $\sim 358,245$ tons of corn must be utilized per year to produce 123,984 tons per year of denatured bioethanol. The corn is the main cost, accounting for $\sim \$ 44 \mathrm{M} \cdot \mathrm{y}^{-1}$ (Table 2). The bioethanol plant operation requires $\sim 11,149$ tons of natural gas to be utilized per year [1]. The cost of natural gas, according to the current gas prices (Table 2), was $\sim \$ 473 \mathrm{~K} \cdot \mathrm{y}^{-1}$. The total costs of the bioethanol plant production were $\sim \$ 58.6 \mathrm{M} \cdot \mathrm{y}^{-1}$. The revenues from bioethanol was $\sim \$ 49 \mathrm{M} \cdot \mathrm{y}^{-1}$ (Supplementary Materials, 
Economic analysis.xlsx, Table 2). Except for the bioethanol, DDGS is produced in the amount of 114,216 ton per year. Usually, it is consumed as an animal feed. According to current DDGS market prices, the revenue value from selling the DDGS is $\sim \$ 14.5 \mathrm{M} \cdot \mathrm{y}^{-1}$ (Table 2, Supplementary Materials, Economic analysis.xlsx). Our calculations indicated that traditional bioethanol plant profit was about $\$ 5 \mathrm{M} \cdot \mathrm{y}^{-1}$ (Table 2, Supplementary Materials, Economic analysis.xlsx).

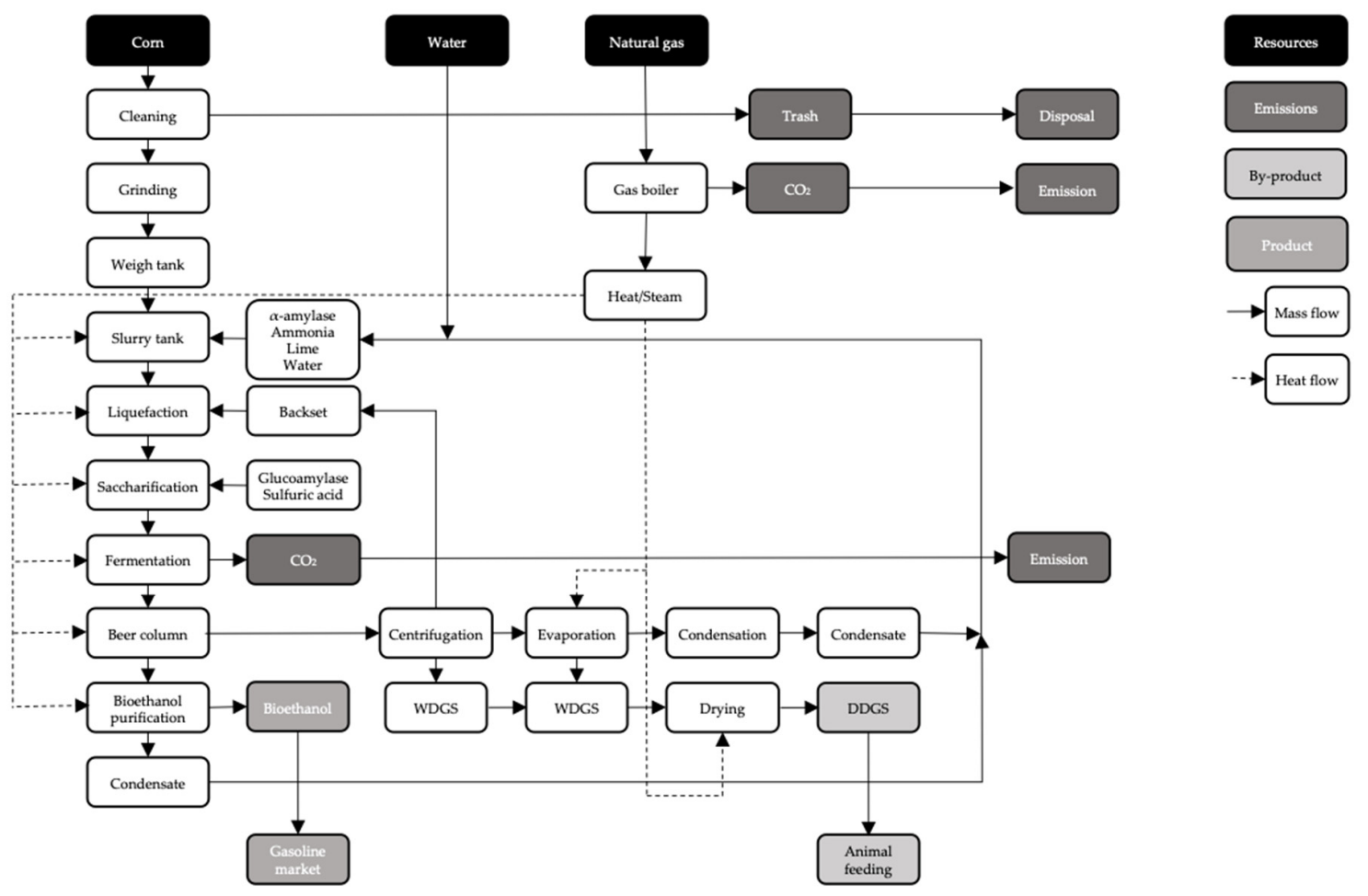

Figure 3. A detailed breakdown of the processes in a conventional ethanol plant.

Concerning the environmental issues related to bioethanol production, the total emission of $\mathrm{CO}_{2}$ $127,884 \mathrm{tCO}_{2} \cdot \mathrm{y}^{-1}$, consisting of the sum of natural gas use $\left(30,659 \mathrm{tCO}_{2} \cdot \mathrm{y}^{-1}\right)$ and fermentation process $\left(97,225 \mathrm{t} \mathrm{CO}_{2} \cdot \mathrm{y}^{-1}\right)$ (Supplementary Materials, Technoeconomic Model.xlsx).

\subsection{Innovative Bioethanol Plant with the CSF Production Techno-Economic Model}

We proposed to valorize DDGS by making fuel from it. Thus, the plant will become energy-neutral by eliminating natural gas burning. An energy-neutral plant does not mean that there is zero additional energy added to the system but rather that it is low and more sustainable, which is what our system proposes. Usually, the bioethanol plant does not have its own electricity production unit and imports the electricity from the grid. The new fuel produced (CSF) can be sold outside and create a new revenue stream. Therefore, we proposed to apply the torrefaction process of DDGS, resulting in the production of CSF, which can be reused for heating the bioethanol plant-'heating' for saccharification, liquefaction, fermentation, ethanol distillation and WDGS drying (12.6\% of CSF produced), and for 'heating' the torrefaction process (3.1\% of CSF produced). The remainder $84.3 \%$ of CSF may be sold on the solid fuel market and be a new source of revenues (Figure 4). 


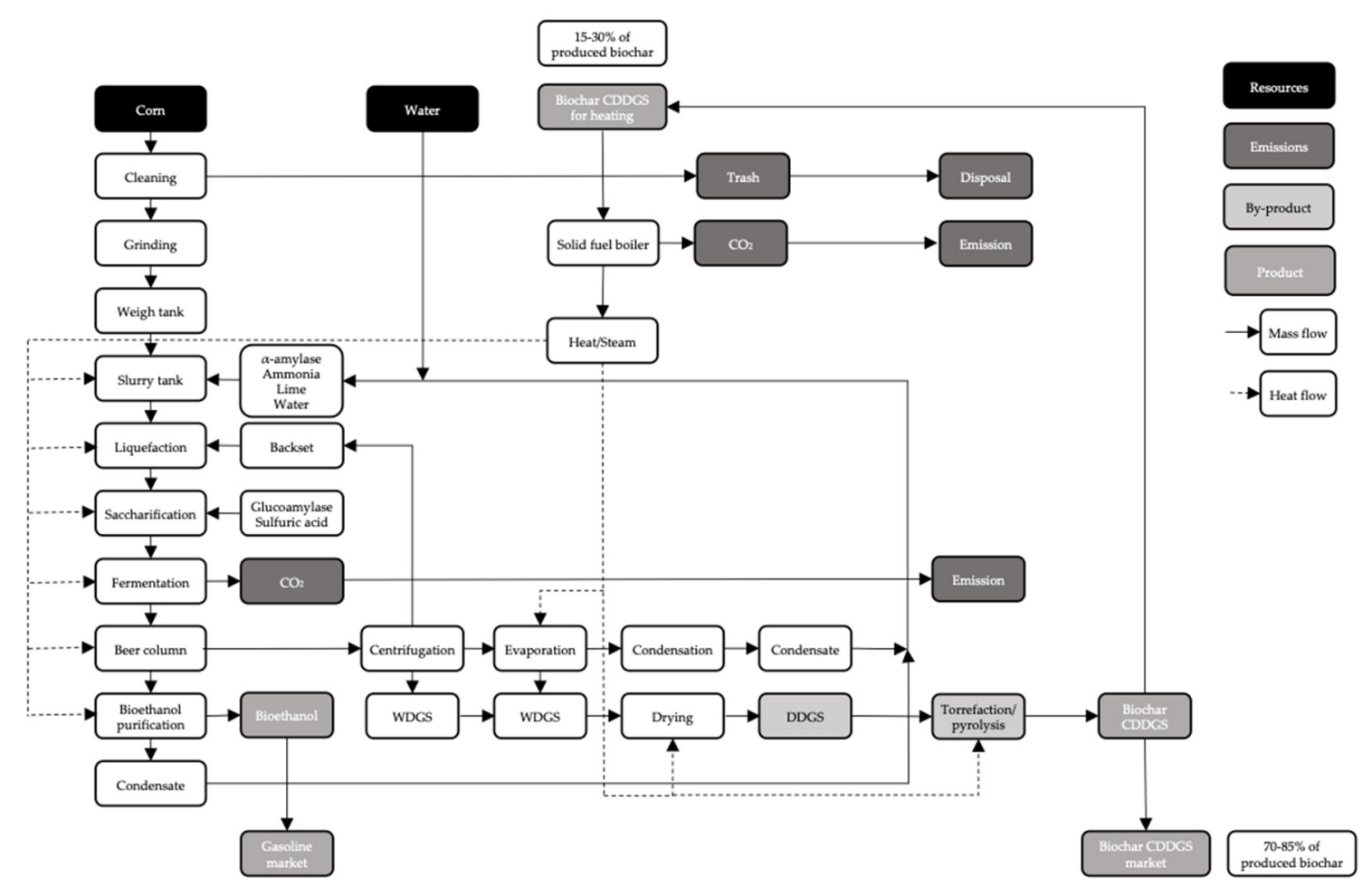

Figure 4. A detailed breakdown of the processes in the proposed ethanol production system.

Accounting the mass yield of DDGS torrefaction $77.3 \%$, the production of CSF should reach $88,289 \mathrm{t}$ per year. The torrefaction of one ton of DDGS requires $624 \mathrm{MJ}$. It means that for the total mass of DDGS, the energy demand on torrefaction is $71,270,784 \mathrm{MJ} \cdot \mathrm{y}^{-1}$. Taking LHV of CSF to be $26.12 \mathrm{MJ} \cdot \mathrm{kg}^{-1}$ d.m. to cover the DDGS energy demand, $\sim 2729 \mathrm{t} \cdot \mathrm{y}^{-1}$ of CSF must be utilized, i.e., as low as $\sim 3.1 \%$ of the total CSF production. Knowing that the bioethanol plant natural gas demand is $11,149 \mathrm{t} \cdot \mathrm{y}^{-1}$ and that the LHV of natural gas is $\sim 26 \mathrm{MJ} \cdot \mathrm{kg}^{-1}, \sim 11,098 \mathrm{t} / \mathrm{year}$ of CSF must be used to substitute the natural gas, i.e., as low as $\sim 12.6 \%$ of the total CSF production. Moreover, the substitution of natural gas by CSF reduces $\mathrm{CO}_{2}$ emission by $30,659 \mathrm{t}$ of $\mathrm{CO}_{2} \cdot \mathrm{y}^{-1}$ (about $24 \%$ of the total $\mathrm{CO}_{2}$ emission). Considering that CSF is a 'green' renewable fuel, the $\mathrm{CO}_{2}$ emission from CSF burning should not be included in the $\mathrm{CO}_{2}$ balance. These calculations showed that $\sim 84 \%\left(\sim 74,462 \mathrm{t} \cdot \mathrm{y}^{-1}\right)$ of CSF might be sold as a high-quality fuel. An additional benefit is that the savings from the natural gas substitution by CSF reach $\sim \$ 472 \mathrm{~K} \cdot \mathrm{y}^{-1}$ (Table 3, Supplementary Materials, Economic analysis.xlsx).

Due to the very high biochar price used for calculations, the overall profit of the bioethanol plant

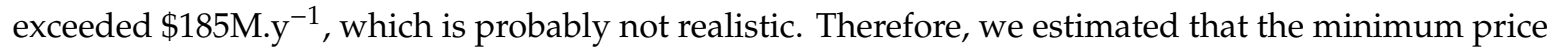
for CSF above which the bioethanol plant has a similar level of profit as the conventional one is about $\$ 188 \cdot \mathrm{t}^{-1}$ (Supplementary Materials, Economic analysis.xlsx). The current market price for biochar is an order of magnitude higher, exceeding $\$ 2600 \cdot \mathrm{t}^{-1}$ [5]. It shows that new products such as CSF may allow the replacement of natural gas and the creation of new, value-added products giving the perspectives to be more profitable, therefore making the bioethanol industry more sustainable.

\section{Discussion}

Overall, the proposed solution increases the bioethanol production sustainability and profitability due to synergy with the thermochemical treatment of DDGS (via torrefaction), reuse of part of the produced CDDGS for covering all plant heat demand, replacing the need to purchase natural gas (fuel), and creating a new revenue stream for a plant. The majority of biochar produced from DDGS can be sold, and thus, be considered as a new revenue stream for a bioethanol plant. 
Ethanol plants are, therefore, faced with the question if the existing production line of the bioethanol plant should be modified to include the DDGS torrefaction unit. The bioethanol industry is a well-developed branch of the economy. However, it suffers from a frequent negative return rate over the operating costs (Figure 5). That situation has been made worse by the COVID-19 pandemic, when both bioethanol and corn prices dropped. Such a situation, when the existing system is suffering from the significant drop of bioethanol and corn prices (lower revenues both for bioethanol plant and farmers), is an opportunity for the implementation of innovations that under normal conditions would not be considered by decisionmakers. There is also a question if such an innovative solution should be integrated with the bioethanol plan or should be a separate unit.

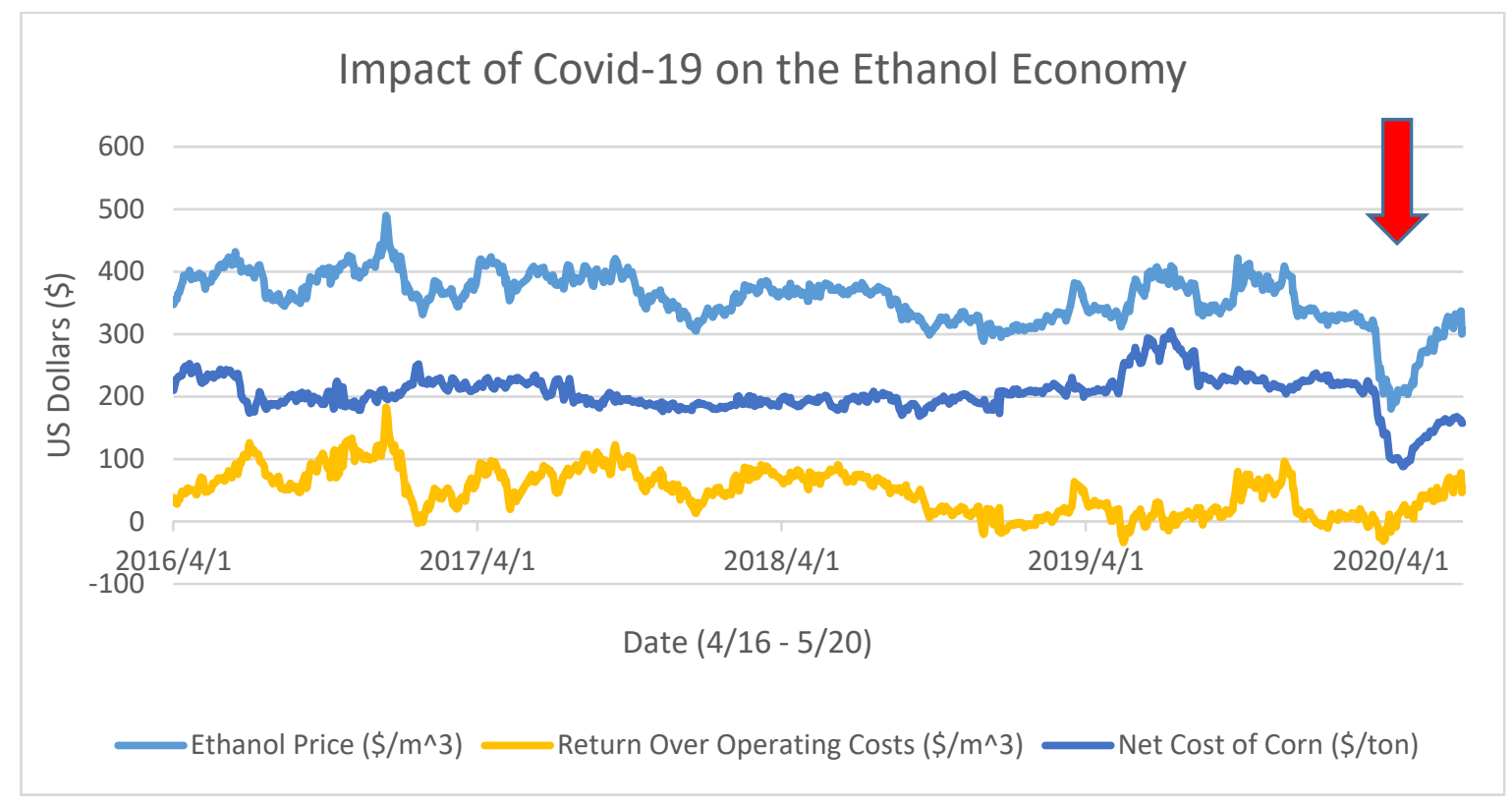

Figure 5. Prices of ethanol (2015-2020) [12]. A red arrow indicates an example of the recent price drop caused by the SARS-Cov-2 outbreak.

Haseli [13] created a model that can be used to provide a rough estimate of what the optimum operating point and energy consumption is for a torrefaction plant. The goal was to create a tool that could provide information on how to maximize net energy gain in a standalone and integrated model. The data used was based on the study of two different types of wood, which is run in both scenarios and used to determine what is the ideal energy consumption to produce the most mass of torrefied material. Haseli [13] model of torrefaction integration with a power plant, suggest a downstream method that requires a separate plant for the torrefaction. We are not proposing a downstream model like Haseli [13]; instead, we are proposing the direct modification of the original process of the dry-grind ethanol production system, which would directly loop the torrefaction of the biological material into the system. Therefore, by the implementation and integration of the torrefaction process with bioethanol plants, there is a synergistic effect causing the increase of economic efficiency. Our model includes previous research from our team on finding the ideal conditions for torrefaction, using DDGS instead of wood, which would maximize the mass yield and calorific value of DDGS.

Kalyian et al. [2] developed a model of a process that integrated torrefied corn stover into the ethanol production system. The goal was to assess whether there was the potential to reduce greenhouse gas emissions through the integration of biomass torrefaction into industrial-scale businesses. Based on the mass of corn stover collected in his model, which was $70 \%$ of corn stover per unit land area on a biannual basis, it would be able to meet $42.8 \%$ of the steam demands of a dry-grind corn ethanol plant in the US. It was found that this would result in a $40 \%$ reduction of greenhouse gas emission for 
corn-based ethanol when compared to gasoline. A paper by Kalyian et al. [2] has a primary focus on the environmental impacts' corn stover torrefaction provides.

Our idea differs from Kalyian et al. [2] in many instances. First and foremost is the choice of biomass. Corn stover is known to be left in field post-harvest for the positive impact it has on the soil, and this is addressed in [2]. Our choice of biomass (DDGS) would not be associated with concerns about amending current agronomic practices that can have a comparably negative impact on soil. In addition, we have found that with the amount of biochar produced from DDGS, we can cover the total energy demands of an ethanol plant while maintaining a significant percentage of biochar left over to be sold.

One of the challenges of the bioeconomy implementation is the overcoming of the problem of high carbon footprint, sustainability, and energy efficiency of the biorefineries. This issue opens a new niche for the ideas, interdisciplinary problem solving, and innovation in the wide field of the bioeconomy. Schipfer and Kranzl [14] addressed the European Union to shift to a biobased system as a means of reducing emissions and fossil fuel usage. The techno-economic evaluation of biomass to the product uses two feedstocks, i.e., wood chips (beechwood) and wheat straw. This paper addressed the possibility of integrating bioenergy into residential and industrial scales. Ortiz et al. [15] performed a review of three different models for sugarcane-based biorefineries. The three options were a conventional biorefinery, a biochemical platform that utilizes bagasse as a fuel for the system, and finally, a thermochemical platform that utilizes gasification. Kumar et al. [16] addressed the differences between the methods of producing conventional biochar (made from dry feedstock) and hydrochar (made from wet feedstock). The generation of conventional biochar used pyrolysis, torrefaction, flash carbonization, and gasification, whereas hydrothermal carbonization generates hydrochar. The findings indicate that a higher energy density can be expected largely due to the lower ash content in the produced hydrochar. In our study, we used conventional torrefaction, which has higher TRL (Technology Readiness Level), i.e., it has already been implemented at the full scale with wood [17], compared to the hydrothermal carbonization, i.e., still at the stage of R\&D and prototyping. However, the next step could be the execution of tests leading to hydrochar production from DDGS, and modeling the influence on the bioethanol plant sustainability and profitability. Manouchehrinejad and Mani [18] used pine wood chips as a feedstock for simulating an integrated biomass torrefaction and pelletization (iBTP) plant for the production of solid biofuels. The simulation found that the $100,000 \mathrm{Mg} \cdot \mathrm{y}^{-1}$ plant could become autothermal for torrefaction over $270{ }^{\circ} \mathrm{C}$ requiring $8.2 \sim 9 \mathrm{MJ} \cdot \mathrm{kg}^{-1}$ for the production of torrefied pellets.

The proposed solution is an innovative creation of the new product biochar from DDGS, which could be called CSF (Carbonized Solid Fuel), with the potential to be marketed for energetic and agricultural applications.

The proposed invention may bring the following benefits:

(1) Elimination of natural gas purchase costs.

(2) A new source of revenue from selling the CSF.

(3) Improved the degree of independence from fluctuations in the raw materials market.

(4) Implementation of the 'circular economy' inside the bioethanol plant.

From a technical-economic point of view, the most important drivers for the development of the bio-based industry are the economic impact and process sustainability [19]. These drivers include the profitability of the company and the environmental performance of the products. Additionally, the policy may be considered a significant driver with a secondary role, although it may become more important in the future because policy acts at the end as a common channel for the demands of society and the strategies of companies. During bio-products generation (bioethanol), part of the biomass will be converted to waste stream-DDGS. This organic waste must be recycled. We propose, for the first time, the implementation of a new solution based on valorization and biowaste recycling according to the 'waste to carbon' and 'waste to energy' approaches. The wet organic waste is prone to decay and is 
difficult to store without drying (and additional energy input for drying is required). The concept of the closing the biomass supply chain due to the torrefaction of DDGS for CSF production, its reuse for the bioethanol plant heat demand covering, and its recycling to the agricultural or energetic purposes falls into the "Roadmap of Transformation to Circular Economy" adopted by the Polish Government in the 2019-a new policy regarding the circular economy, including the bioeconomy [20]. Torrefaction is a technology that can serve as a basis for the development of other technologies, by acting as a preprocessing technology prior to the use of other processes, whether for energy production or for biorefineries for green chemicals. The use of torrefaction as a pretreatment technology allows the gasification process to be much more efficient than when starting from thermally unprocessed biomass. The production of more advanced forms of materials with high fixed carbon contents, such as charcoal, coke, and activated charcoal, are also promising possibilities that will aid with the development of new nanotechnology products, for example, by supplying carbon for the production of graphene, or activated charcoal for the removal of toxic compounds [21].

Nowadays, the torrefaction of biomass is a developing technology. Still, due to the characteristics of the resulting products, it generates the interest of the sector's investors. From this perspective, the potential development of biomass thermal conversion technologies, such as torrefaction and/or carbonization, is considered promising regarding the utilization of new forms of biomass; namely, the less environmentally-friendly, more abundant, and faster-growing forms, as is the case of shrub plants [22] or DDGS as in the presented case. The torrefaction cannot yet be considered as a mature technology, thus, a significant investment in R\&D is still needed [22], including the integration with bioethanol plant or other biorefineries.

We intended to present the proof-of-the-concept of such a synergistic combination of bioethanol plant with DDGS torrefaction and biochar recycling. However, in this paper, we included the economic model (Supplementary Materials, Economic analysis.xlsx) by inserting the process data related to the ton of corn, where potential users could input their data of the mass of corn, from their bioethanol plants to do the calculations of potential benefits from application of our idea. In the model, they can input data about the mass of corn, mass of ethanol, mass of natural gas, mass of DDGS, and mass of CSF. The model will calculate the final revenues considering all possible costs.

The presented model is the proof-of-the-concept, which should be further studied, including scaling up the system, integration of the devices, life cycle assessment, and final feasibility study, before the implementation.

\section{Conclusions}

The proposed solution is an innovative change in the bioethanol production scheme due to:

- Addition of a torrefaction unit for thermochemical treatment of DDGS and production of biochar (CSF) characterized by the lower calorific value (LCV) $<\sim 30 \mathrm{MJ} \cdot \mathrm{kg}^{-1}$ and $>19 \mathrm{MJ} \cdot \mathrm{kg}^{-1}$;

- Substitution of natural gas (currently used as a heat source in a gas boiler) with CSF and incineration in a solid fuel boiler. It can result in the monetary profits $\$ 473 \mathrm{~K} \cdot \mathrm{y}^{-1}$ due to savings of the cost of the natural gas that would no longer be needed. Depending on the market, when the price of the CSF is higher than $\$ 188 \cdot \mathrm{t}^{-1}$, the bioethanol plant could start to make a profit at a higher rate than a conventional one.

- Use of heat generated from CSF incineration in solid fuel boiler for covering entire heat demands of torrefaction unit and the heat demand of bioethanol production line (15-30\% of the mass of CSF and depending on LHV of CSF produced).

- In total, $70-85 \%$ of the CSF produced has the potential to be marketed for energetic, agricultural, and other applications.

- The substitution of natural gas by CSF reduces $\mathrm{CO}_{2}$ emission by $\sim 24 \%$ of the total $\mathrm{CO}_{2}$ emission of the bioethanol plant. 
- The application of DDGS torrefaction and CSF recycling may be a source of the new, more valuable revenues and bring new perspectives to the bioethanol industry to be more sustainable and profitable, including during the COVID-19 (or other diseases) pandemic and other extreme market conditions.

\section{Patents}

The early version of the work described in this manuscript was submitted to Iowa State University as an Invention Disclosure [23] Koziel, J.A., S. O’Brien, C. Banik, A. Bialowiec. Energy-neutral bioethanol production plant. Iowa State University. Invention Disclosure Docket No. 05017. (Submitted on 9 October 2019).

Supplementary Materials: The following are available online at http://www.mdpi.com/1996-1073/13/17/4528/s1, Technoeconomic Model.xlsx, and Economic analyses.xlsx.

Author Contributions: Conceptualization, A.B., S.O., and J.A.K.; methodology, A.B., S.O., J.A.K., and C.B.; software, S.O. and A.B.; validation, S.O. and A.B.; formal analysis, S.O., J.A.K., A.B., and C.B.; investigation, S.O. and A.B.; resources, A.B., S.O., J.A.K., and C.B.; data curation, A.B., S.O., and J.A.K.; writing-original draft preparation, S.O.; writing-review and editing, A.B., S.O., J.A.K., and C.B.; visualization, A.B., S.O., and J.A.K.; supervision, A.B. and J.A.K.; project administration, A.B. and J.A.K.; funding acquisition, A.B. and J.A.K. All authors have read and agreed to the published version of the manuscript.

Funding: The authors would like to thank the Fulbright Foundation for funding the project titled "Research on pollutants emission from Carbonized Refuse-Derived Fuel into the environment," completed at the Iowa State University. In addition, this paper preparation was partially supported by the Iowa Agriculture and Home Economics Experiment Station, Ames, Iowa. Project no. IOW05556 (Future Challenges in Animal Production Systems: Seeking Solutions through Focused Facilitation) sponsored by Hatch Act and State of Iowa funds.

Acknowledgments: The authors are thankful to the Iowa State University Honors Program for facilitating the research mentoring matching for Samuel O'Brien via the Honors First-Year Mentor Program. The presented article results were obtained as part of the activity of the leading research team-Waste and Biomass Valorization Group (WBVG), https://www.upwr.edu.pl/research/50121/waste_and_biomass_valorization_group_wbvg.html.

Conflicts of Interest: The authors declare no conflict of interest.

\section{References}

1. Kwiatkowski, J.R.; McAllon, A.J.; Taylor, F.; Johnston, D.B. Modeling the process and costs of fuel ethanol production by the corn dry-grind process. Ind. Crops Prod. 2006, 23, 288-296. [CrossRef]

2. Kaliyan, N.; Morey, R.V.; Tiffany, D.G.; Lee, W.F. Life cycle assessment of a corn stover torrefaction plant integrated with a corn ethanol plant and a coal fired power plant. Biomass Bioenergy 2014, 63, 92-100. [CrossRef]

3. Rosentrater, K.A. Ethanol processing coproducts-A review of some current constraints and potential directions. Int. Sugar J. 2007, 109, 1-12.

4. Świechowski, K.; Syguła, E.; Koziel, J.A.; Stępień, P.; Kugler, S.; Manczarski, P.; Białowiec, A. Low-temperature pyrolysis of municipal solid waste components and refuse-derived fuel-Process efficiency and fuel properties of carbonized solid fuel. Data 2020, 5, 48. [CrossRef]

5. Hofstrand, D. 07.01.2020. Available online: http://www.extension.iastate.edu/agdm/energy/xls/d110ethanolprofitability.xlsx (accessed on 19 August 2020).

6. ARTi. Available online: https://artichar.com (accessed on 27 June 2020).

7. Swiechowski, K.; Stepien, P.; Hnat, M.; Kugler, S.; Stegenta-Dabrowska, S.; Koziel, J.A.; Manczarski, P.; Bialowiec, A. Waste to carbon: Biocoal from elephant dung as new cooking fuel. Energies 2019, 12, 22.

8. Bioagra. Available online: https://bioagra.pl/en/products/ddgs-distillers-dry-grains-with-solubles/ (accessed on 25 June 2020).

9. Syguła, E.; Koziel, J.A.; Białowiec, A. Proof-of-concept of spent mushrooms compost Torrefaction-Studying the process kinetics and the influence of temperature and duration on the calorific value of the produced biocoal. Energies 2019, 12, 3060. [CrossRef]

10. Polish Committee for Standardization. Solid Biofuels—Determination of Calorific Value. PN-EN ISO 18125:2017-07, 12 July 2017. 
11. Chin, K.L.; H'ng, P.S.; Go, W.Z.; Wong, W.Z.; Lim, T.W.; Maminski, M.; Paridah, M.T.; Luqman, A.C. Optimization of torrefaction conditions for high energy density solid biofuel from oil palm biomass and fast growing species available in Malaysia. Ind. Crops Prod. 2013, 49, 768-774. [CrossRef]

12. Center for Agricultural and Rural Development. Available online: https://www.card.iastate.edu/ (accessed on 23 June 2020).

13. Haseli, Y. Simplified model of torrefaction-grinding process integrated with a power plant. Fuel Process. Technol. 2019, 188, 118-128. [CrossRef]

14. Schipfer, F.; Kranzl, L. Techno-economic evaluation of biomass-to-end-use chains based on densified bioenergy carriers (dBECs). Appl. Energy 2019, 239, 715-724. [CrossRef]

15. Ortiz, P.A.S.; Maréchal, F.; de Oliveira Junior, S. Exergy assessment and techno-economic optimization of bioethanol production routes. Fuel 2020, 279, 118327. [CrossRef]

16. Kumar, A.; Saini, K.; Bhaskar, T. Review-Hydrochar and biochar: Production, physicochemical properties and technoeconomic analysis. Bioresour. Technol. 2020, 310, 123442. [CrossRef] [PubMed]

17. Thrän, D.; Witt, J.; Schaubach, K.; Kiel, J.; Carbo, M.; Maier, J.; Ndibe, C.; Koppejan, J.; Alakangas, E.; Majer, S.; et al. Moving torrefaction towards market introduction-Technical improvements and economicenvironmental assessment along the overall torrefaction supply chain through the SECTOR project. Biomass Bioenergy 2016, 89, 184-200. [CrossRef]

18. Manouchehrinejad, M.; Mani, S. Process simulation of an integrated biomass torrefaction and pelletization (iBTP) plant to produce solid biofuels. Energy Convers. Manag. X 2019, 1, 100008. [CrossRef]

19. Nattrass, L.; Biggs, C.; Bauen, A.; Parisi, C.; Rodríguez-Cerezo, E.; Gómez-Barbero, M. The EU Bio-Based Industry: Results from a Survey. Joint Research Centre, 2016. Available online: http://publications.jrc.ec. europa.eu/repository/bitstream/JRC100357/jrc100357.pdf (accessed on 3 August 2020).

20. Prime Minister Office. Government of Poland. Resolution on the Adoption of the "Roadmap for Transformation towards a Circular Economy", 10 September 2019. Available online: https://www.premier.gov.pl/wydarzenia/ decyzje-rzadu/uchwala-w-sprawie-przyjecia-mapy-drogowej-transformacji-w-kierunku.html) (accessed on 3 August 2020).

21. Nunes, L.J.R.; Matias, J.C.O. Biomass torrefaction as a key driver for the sustainable development and decarbonization of energy production. Sustainability 2020, 12, 922. [CrossRef]

22. Ribeiro, J.M.C.; Godina, R.; Matias, J.C.O.; Nunes, L.J.R. Future perspectives of biomass torrefaction: Review of the current state-of-the-art and research development. Sustainability 2018, 10, 2323. [CrossRef]

23. Koziel, J.A.; O’Brien, S.; Banik, C.; Bialowiec, A. Energy-Neutral Bioethanol Production Plant. Invention Disclosure Docket No. 05017, 9 October 2019.

(C) 2020 by the authors. Licensee MDPI, Basel, Switzerland. This article is an open access article distributed under the terms and conditions of the Creative Commons Attribution (CC BY) license (http://creativecommons.org/licenses/by/4.0/). 